\title{
The Effect of Corporate Governance on Sharia Corporate Performance in Indonesia
}

\author{
Roghiebah Jadwa Faradisi ${ }^{1}$, Dyah Setyaningrum ${ }^{1 *}$ \\ ${ }^{1}$ Faculty of Economics and Business, Universitas Indonesia, Depok 16424, Indonesia \\ ${ }^{*}$ Corresponding Author: dsetyani@ui.ac.id
}

\begin{abstract}
This research aims to examine the effect of corporate governance on Sharia corporate performance. Corporate governance is measured using the effectiveness of Boards of Commissioners and Audit Committees. We score this effectiveness using the activity, competency, size and independence of the Board of Commissioners and the Audit Committee, while Tobin's Q is used to measure Sharia corporate performance. The sample for this study is 63 Sharia manufacturing companies listed on the Indonesia Stock Exchange and on the Sharia Stock List released by the Indonesia Financial Services Authority from 2014 to 2015. Using multiple regression, the results show that Board of Commissioners and Audit Committee effectiveness has positive effect on Sharia corporate performance. Based on this result, Sharia companies should increase the effectiveness of their Boards of Commissioners and Audit Committees, as it is used by investors to make investment decisions.
\end{abstract}

Keywords: Audit Committee; Board of Commissioner; Corporate Governance; Corporate Performance; Tobin's Q.

\section{INTRODUCTION}

Islamic Economics in Indonesia has grown over time. In March 2015, the Indonesia stock exchange mentioned that there were 351 issuers of Sharia stock. The capitalization of Sharia shares was $48 \%$ of the total shares listed on the Indonesia stock exchange and reached Rp2,946.89 billion $^{1}$. Sharia economic development is also triggered by the high degree of public awareness of halal and Islamic consumption behavior. This is proven by the increase in the amounts of zaka and infaq endowments collected and transmitted by the agency that manages the funds ${ }^{2}$. Sharia companies do not produce or distribute non-halal products; nor do they perform activities that violate Islamic principles.

Rapid development of Sharia business creates promising investment alternatives for investors. Investors feel more confident about investing in Sharia-based companies because these companies implement Islamic principles and historically show better growth compared with conventional companies ${ }^{1}$. Given that Indonesia is the country with the world's largest Muslim majority, investment in Sharia stock has huge profit potential. To encourage the rise of the Islamic economic system in Indonesia, the financial services authority (OJK) sets out the Sharia Stock List, which is reviewed once every six months and contains certain specific criteria. The list of Sharia Stocks serves as an investment guideline for users such as Sharia insurance and mutual fund managers and investors, and also for Sharia index providers such as the Jakarta Islamic Index and the Indonesia Sharia Stock Index ${ }^{3}$.

Good corporate performance is influenced by various factors, one of which is corporate governance. Corporate governance is a set of mechanisms that provide direction and control of the company's operational activities in order to align with the stakeholder's goals. Good corporate governance will increase a company's financial performance and create better market value ${ }^{4}$. Corporate governance in this research focuses on two elements, namely the effectiveness of the Board of Commissioners and of the Audit Committee. Hermawan established a method for scoring the effectiveness of Boards of Commissioners and Audit Committees, which consists of activity, competency, size and independence ${ }^{5}$. We modified Hermawan scoring using the list of questions contained in the ASEAN Corporate Governance Scorecard.

Several previous studies have been conducted on the corporate governance and performance of Sharia companies, but the majority have been conducted for Islamic finance companies that have already established standards from the National Sharia Council of the Indonesian Ulama Council (DSN MUI). Some previous research has found positive associations between corporate governance and Sharia company performance ${ }^{6-10}$. In contrast, Abdullah found no association between corporate governance and Sharia company performance ${ }^{11}$. This mixed result highlights the importance of conducting research on the association between corporate governance and Sharia corporate performance in Indonesia, especially in Sharia manufacturing companies, which are rarely explored. 
The purpose of the study is to examine the positive effect of Boards of Commissioners' and Audit Committees' effectiveness on the performance of Sharia manufacturing companies in Indonesia. The contribution of this study is that we have modified the scoring of the effectiveness of Boards of Commissioners and Audit Committees from Hermawan $^{5}$ using the list from the ASEAN Corporate Governance Scorecard. We added several questions to enhance the activities of Boards of Commissioners and Audit Committees.

\section{LITERATURE REVIEW AND HYPOTHESIS DEVELOPMENT}

Corporate governance is a good structure and systems for managing a company by increasing shareholder value to accommodate a wide range of interested parties (stakeholders), such as: creditors, suppliers, business associations, consumers, workers, Government, and society ${ }^{11}$. To achieve their optimum objectives, companies need to implement the principles of corporate governance so that they can continue to provide benefits to the welfare of stakeholder interests ${ }^{8}$. According to the Organization for Economic Corporation and Development (OECD), there are some basic principles that have to be met in the implementation of corporate governance concern, such as transparency, accountability, responsibility, independence and fairness ${ }^{12}$.

Corporate Governance has its own mechanisms. This research focuses on two such mechanisms, namely the effectiveness of the Board of Commissioners and of the Audit Committee. The Board of Commissioners is divided into two categories, namely the independent and non-independent commissioners ${ }^{13}$. Independent commissioners are those who do not come from parties affiliated with the company.

In order to complete the tasks of the Board of Commissioners, other committees need to be formed, one of which is the Audit Committee. The role of the Audit Committee is to optimize internal oversight of the company ${ }^{13}$. The audit committee contributes by bridging the connection between the external auditors and the company's internal auditors. The audit committee thus holds an important role in corporate governance. According to OJK, the task of the audit committee is to provide assessment of the financial report, so that the financial statements published are reliable and high quality ${ }^{14}$.

\section{Hypothesis Development}

The Board of Commissioners is the core of the corporate governance mechanism to ensure the implementation of the corporate strategy, overseeing the management of the company and requiring the implementation of accountability ${ }^{13}$. Hermawan states that the effectiveness of the Board of Commissioners can be viewed in terms of four characteristics, namely independence, activities, competencies, and size. Those four characteristics can encourage the effectiveness of the Board of Commissioner ${ }^{5}$. The management of the Sharia company does not produce and distribute non-halal products and is prohibited to conduct activities that violate Islamic principles. It is certainly aligned with the principles of corporate governance: i.e. openness, accountability, responsibility, independence, and fairness. This supports the role of the Board of Commissioners to increase companies' performance.

Brick, Widiawati and Erfina found that number of meetings and commissioner independence have a positive effect on company performance ${ }^{15-17}$. Based on the literature review and previous research, the first hypothesis of this research can be formulated as follows:

H1: The effectiveness of the Board of Commissioners has a positive effect on Sharia corporate performance.

In addition to being able to work effectively, the Board of Commissioners is also assisted by an independent Audit Committee in overseeing performance management within the company. The tasks of the Audit Committee are to provide assessment of the financial report so that the financial statements published are reliable and of high quality ${ }^{14}$. Hermawan mentioned that the effectiveness of the Audit Committee can be seen from three characteristics: i.e., size, activities and competencies ${ }^{5}$.

Riniati, Mulyati and Febhiant found that the activity of the Audit Committee has a positive effect on Sharia corporate performance ${ }^{18-20}$. Based on the literature review and previous research, the second hypothesis of this research can be formulated as follows:

H2: The effectiveness of the Audit Committee has a positive effect on Sharia corporate performance.

\section{RESEARCH METHOD \\ Data}

This study uses secondary data, taken by reading and analyzing annual reports, other reports and annual general meetings. The population in the study is Sharia manufacturing companies listed on the Indonesia stock exchange for the period 2014-2015. Based on the OJK Sharia Stock List, there were 230 Sharia manufacturing companies listed on the BEI during the year 2014-2015. The sample in this study is selected using purposive sampling and we use 63 firms or 126 firm year observations. 


\section{Research Model}

The research model is used to examine the influence of the effectiveness of the Board of Commissioners and the Audit Committee against the performance of the company, namely:

TOBIN $_{\text {it }}=\alpha+\beta_{1}$ DEKOM $_{\text {it }}+\beta_{2}$ KOMDIT $_{\text {it }}+\beta_{3} \mathrm{CR}_{\text {it }}+\beta_{4} \mathrm{DR}_{\text {it }}+\beta_{5} \mathrm{SIZE}_{\mathrm{it}}+\beta_{6} \mathrm{TOBIN}_{\mathrm{it}-1}+\mathrm{e}_{\mathrm{it}} \ldots$

Where TOBIN $=$ value of Tobin's $\mathrm{Q}$, DEKOM $=$ Board of Commissioners' effectiveness, KOMDIT $=$ Audit Committee's effectiveness, $\mathrm{DR}=$ leverage, $\mathrm{CR}=$ profitability ratio, $\mathrm{SIZE}=\log$ company total assets, $\mathrm{TOBIN}_{\mathrm{t}-1}=$ lag value of Tobin's Q year.

Companies' market performance is measured using Tobin's $Q$ because market-based measurement is considered more objective in measuring the company's financial performance and free from manipulation. Market-based measurements are capable of representing investment judgments about the company's ability to generate economic returns in the future. Wolfe and Sauaia ${ }^{21}$ mentioned that measurements with Tobin's Q are also capable of representing the firm's financial performance reliably. This is because the calculation of Tobin's Q is quite complex, combining the market value and the book value of the company. A Tobin's Q ratio above one (1) indicates that investment in assets generates profits that deliver higher value than investment expenditures, which will stimulate new investment.

To measure the effectiveness of Boards of Commissioners and Audit Committees, we follow Hermawan ${ }^{5}$, with some modification to the ASEAN CG Scorecard by adding questions on Board of Commissioners activity: (1) does the Board of Commissioners schedule the meeting agenda prior to the start of the financial year, (2) does the company set a minimum quorum of $2 / 3$ members of the board of commissioners in determining a policy/decision, and (3) does the company review its vision, mission and strategy in the end of year report? On the size of the Board of Commissioners, we add a question about whether the company has at least one independent female commissioner. On the Audit Committee element, we add the question of whether there is an audit committee statement regarding the adequacy of the company's internal controls.

The Hermawan questionnaire contains 24 questions on the effectiveness of the Board of Commissioners and 12 questions on the effectiveness of the Audit Committee. In this study we add 4 questions on the effectiveness of the Board of Commissioners and 1 question on the effectiveness of the Audit Committee, so that the total number of questions is 38 .

\section{RESULTS AND DISCUSSIONS \\ Descriptive Statistics Test Results}

Table 1 presents the descriptive statistics of the variables. From the descriptive statistics, it can be seen that the average Tobin's Q in Indonesian Sharia manufacturing companies is 0.91720 , which means that the value of the company is less able to stimulate investments because the score is less than 1. A Tobin's Q Score that is less than 1 indicates that the investment in assets less profit gives a higher value than investment expenditure, so it is possible that the investments made by these companies are not in the form of investment assets.

Table.1. Descriptive Statistics

\begin{tabular}{lcrrrr}
\hline & N & \multicolumn{1}{c}{ Min } & \multicolumn{1}{c}{ Max } & \multicolumn{1}{c}{ Mean } & Std. Dev. \\
\hline TOBIN & 80 & -0.187 & 3.343 & 0.917 & 0.829 \\
DEKOM & 80 & 0.587 & 0.773 & 0.677 & 0.043 \\
KOMDIT & 80 & 0.564 & 0.923 & 0.776 & 0.072 \\
CR & 80 & 0.602 & 8.089 & 2.414 & 1.606 \\
DR & 80 & 0.100 & 0.742 & 0.413 & 0.163 \\
SIZE (billion rupiah) & 80 & 96.75 & 276383.6 & 1156.37 & 3.973 \\
TOBIN t-1 & 80 & 0.000 & 3.646 & 1.017 & 0.922 \\
Valid N (listwise) & 80 & & & & \\
\hline
\end{tabular}

The average effectiveness score of the Sharia-compliant manufacturing companies' Boards of Commissioners in Indonesia is 0.67700 , which means that they are rated fair. The average score for the effectiveness of the Audit Committees is 0.77628 , which means that the audit committees of Sharia manufacturing companies in Indonesia are already working effectively.

Based on a breakdown of the components in terms of the independence of the Boards of Commissioners, Sharia-compliant companies in Indonesia have good independence and activities, but their size has not met the criteria for good corporate governance, which requires the committee to have at least five members. The Audit Committees of Sharia-compliant companies in Indonesia can be judged to have sufficient activity and their size already qualifies for good corporate governance, which requires that a company's audit committee has at least three members with good competence. 


\section{Hypothesis Testing}

Table.2. Hypothesis Testing

\begin{tabular}{lccrlr}
\hline \multicolumn{1}{c}{ Variable } & Exp. Sign & Coeff. & \multicolumn{1}{c}{ t } & Sig & $\alpha$ \\
\hline (Constant) & & -1.749 & -2.381 & 0.119 & \\
DEKOM & H1 $(+)$ & 2.990 & 3.837 & 0.029 & $* *$ \\
KOMDIT & $\mathrm{H} 2(+)$ & 1.171 & 2.756 & 0.086 & $* * *$ \\
CR & + & -0.070 & -2.363 & 0.121 & \\
DR & - & -0.270 & -0.931 & 0.321 & \\
SIZE & + & -0.024 & -0.865 & 0.667 & \\
TOBIN t-1 & + & 0.661 & 17.894 & 0.000 & $*$ \\
\hline \multicolumn{7}{l}{ The number of observations $=80$} \\
Adjusted R Square $=0.614$ \\
\hline
\end{tabular}

\section{The Effectiveness of the Board of Commissioners Positively Effects on Corporate Performance}

The results of this research show that the effectiveness of the Board of Commissioners has a positive effect on performance. The tasks of the Board of Commissioners are well-executed and encourage achievement of the companies' objectives. Independent Commissioners are appointed using certain criteria in line with the principles of good corporate governance, namely greater transparency: this is also in line with the principles of Islamic economy - the amanah.

A Board of Commissioners with good knowledge in terms of finance can improve the performance of the company and subsequently increase investors' confidence in investing their funds in the company, so that the value of the performance market (Tobin's Q) will increase.

\section{The Effectiveness of the Audit Committee Positively Effects on Corporate Performance}

The results of this research show that an Audit Committee that works effectively can improve the company's performance as measured by Tobin's Q. The tasks of the Audit Committees are being performed well, helping the Board of Commissioners to achieve of the company objectives. The Audit Committee has at least three members and has good knowledge in terms of finance to help improve company performance. In addition, the Audit Committee regularly examines the company's financial statements to assist the Board of Commissioners in enhancing investors' confidence in investing their funds in the company, so that the value of the performance market (Tobin's Q) increased.

\section{CONCLUSION}

The purpose of this study was to examine the positive effect of Board of Commissioners and Audit Committee effectiveness on the performance of Sharia manufacturing companies in Indonesia. Corporate governance was measured using Boards of Commissioners' and Audit Committees' effectiveness. We used Hermawan's measure modified with the ASEAN CG Scorecard, and used four components to measure effectiveness, namely activity, competency, size and independence. Corporate Performance was measured using Tobin's Q. The sample for this study comprised 63 Sharia manufacturing companies listed on the Indonesia Stock Exchange and on the Sharia Stock List released by the Indonesia Financial Services Authority from 2014-2015.

The results show that the effectiveness of the Board of Commissioners and the Audit Committee has a positive effect on Sharia corporate performance. Based on these results, Boards of Commissioners and Audit Committees that work effectively can help to improve the company's performance, particularly in stock market performance. It is implied that Sharia companies should increase the effectiveness of their Boards of Commissioners and Audit Committees, as this measure is used by investors to make investment decisions.

An important implication of this study is that the Financial Services Authority (OJK) needs to develop corporate governance assessment for Sharia companies, not only for financial institutions, as to date we use scoring systems employed by conventional companies. For example, in measuring the effectiveness of a Board of Commissioners, Sharia companies must also include the competence, activity, size and independence of the Sharia Board of Trustees.

The limitation of the study is the subjectivity of the assessment of corporate governance scores. Further research should consider the use of teams to prepare the assessments to minimize such subjectivity. Further research should also consider other corporate governance mechanisms, such as considering the effect of managerial and institutional ownership, risk management committees, remuneration committees and Boards of Sharia Trustees. 


\section{REFERENCES}

[1] M Mahfuz. Perkembangan Ekonomi Syariah dan Peran Sertanya dalam Pembangunan Indonesia. Accessed from http://www.globalmulia.ac.id/berita-perkembangan-ekonomi-syariah-dan-peran-sertanya-dalam-pembangunanindonesia.html\#ixzz4wb4EGoTs (2016).

[2] A Firdaus, E Prianto. Pengukuran kinerja bisnis berbasis syariah dengan maslahah scorecard. Review of Islamic Economics, Finance, and Banking, 1(2) (2013) 233-252.

[3] Otoritas Jasa Keuangan (OJK). Penerbitan Keputusan Dewan Komisioner Otoritas Jasa Keuangan tentang Daftar Efek Syariah. Otoritas Jasa Keuangan (OJK), Jakarta (2013).

[4] Forum for Corporate Governance in Indonesia (FCGI). Seri Tata Kelola Perusahaan (Corporate Governance), Edisi Ke-2. Forum for Corporate Governance in Indonesia FCGI, Jakarta (2001).

[5] AA Hermawan. Pengaruh Efektifitas Dewan Komisaris dan Komite Audit, Kepemilikan oleh Keluarga, dan Peran Monitoring Bank terhadap Kandungan Informasi Laba. Dissertation, Universitas Indonesia (2009).

[6] P Niawati. Analisis Pengaruh Penerapan Corporate Governance, Kepemilikan, dan Ukuran (Size) Bank terhadap Kinerja Bank. Thesis, Universitas Indonesia (2011).

[7] E Eduardus, J Juniarti. Kinerja sosial perusahaan dan kinerja keuangan perusahaan yang diukur menggunakan Tobin's Q. Business Accounting Review, 4(1) (2016) 517-528.

[8] S Asba. Pengaruh Corporate Governance, Asset dan Growth terhadap Kinerja Pasar. Undergraduate Thesis, Universitas Gunadarma (2009).

[9] W Al-Haddad, ST Alzurqan, FJ AlSufy. The effect of corporate governance on the performance of Jordanian industrial companies: An empirical study on Amman Stock Exchange. International Journal of Humanities and Social Science, 1(4) (2011) 55-69.

[10] MS Darweesh. Correlations between Corporate Governance, Financial Performance, and Market Value. Dissertation, Walden University (2015).

[11] A Abdullah, M Page. Corporate Governance and Corporate Performance: UK FTSE 350 Companies. The Institute of Chartered Accountants of Scotland, Edinburgh (2009).

[12] Organisation for Economic Co-operation and Development (OECD). OECD Principles of Corporate Governance. Organisation for Economic Co-operation and Development (OECD), Paris (2004).

[13] Komite Nasional Kebijakan Governance (KNKG). Pedoman Umum Good Corporate Governance Indonesia. Komite Nasional Kebijakan Governance (KNKG), Jakarta (2006).

[14] Otoritas Jasa Keuangan (OJK). Peraturan Otoritas Jasa Keuangan Nomor 55/POJK.04/2015 tentang Pembentukan dan Pedoman Pelaksanaan Kerja Komite Audit. Otoritas Jasa Keuangan (OJK), Jakarta (2015).

[15] IE Brick, NK Chidambaran. Board Meetings, Committee Structure, and Firm Performance. Accessed from https://papers.ssrn.com/sol3/papers.cfm?abstract_id=1108241 (2007).

[16] HS Widiawati. Pengaruh Corporate Governance terhadap Kinerja Keuangan (Studi Empiris pada Perbankan di Bursa Efek Indonesia). Thesis, Universitas Sebelas Maret (2011).

[17] E Erfina. Pengaruh Corporate Governance terhadap Kinerja Keuangan Perbankan Syariah di Indonesia. Undergraduate Thesis, Universitas Muhammadiyah Surakarta (2014).

[18] K Riniati. Pengaruh Komisaris Independen dan Komite Audit terhadap Kinerja Perusahaan (Perusahaan yang Terdaftar di BEI 20112013). Undergraduate Thesis, Universitas Negeri Yogyakarta (2015).

[19] SM Mulyati. Pengaruh Penerapan Good Corporate Governance terhadap Kinerja Keuangan Perusahaan (Studi pada Perusahaan Manufaktur yang Terdaftar di Bursa Efek Indonesia Periode 2007-2009). Undergraduate Thesis, Universitas Negeri Semarang (2011).

[20] C Febhiant, D Setyaningrum. Pengaruh Corporate Governance dan Kepemilikan Keluarga terhadap Nilai Perusahaan (Studi Empiris Perusahaan Manufaktur yang Terdaftar di BEI Periode 2010-2011). Undergraduate Thesis, Universitas Indonesia (2013).

[21] J Wolfe, ACA Sauaia. The Tobin's Q as a company performance indicator. Development in Business Simulation and Experiential Learning, 30 (2003) 155-159. 